\title{
Integrin Alpha-L
}

National Cancer Institute

\section{Source}

National Cancer Institute. Integrin Alpha-L. NCI Thesaurus. Code C17372.

Integ rin alpha-L (1170 aa, $129 \mathrm{kDa}$ ) is encoded by the human IT GAL gene. This protein plays a role in cell motility and cell-cell adhesion. 